\title{
CORRIGENDUM
}

\section{A stress-induced early innate response causes multidrug tolerance in melanoma}

D Ravindran Menon, S Das, C Krepler, A Vultur, B Rinner, S Schauer, K Kashofer, K Wagner, G Zhang, E Bonyadi Rad, NK Haass, HP Soyer, B Gabrielli, R Somasundaram, G Hoefler, M Herlyn and H Schaider

Oncogene advance online publication, 26 January 2015; doi:10.1038/onc.2014.432

Correction to: Oncogene advance online publication, 24 November 2014; doi:10.1038/onc.2014.372

In this article, published online 24 November 2014, the authors have noticed that the latest supplementary information was not used.
The corrected supplementary information (Supplementary Materials) appears online together with this corrigendum. The authors would like to apologise for any inconvenience this may cause. 